\title{
MANAGING SOCIAL PREJUDICATION AND RELIGIOUS ETHNIC STEREOTYPES THROUGH PSYCHOLOGICAL AND GLOBAL EDUCATION
}

\author{
SYAFRIANTO TAMBUNAN \\ IAIN Padangsidimpuan \\ Email: jasnonebo21@gmail.com
}

\begin{abstract}
Abstrak
Serangkaian konflik yang kita lihat terjadi di Indonesia tidak terlepas dari etnis persoalan agama dan budaya, terdapat faktor-faktor seperti kesenjangan struktural dan ketidakadilan sistem. Realitas faktual ini kiranya dapat memunculkan potensi konflik, artinya bahaya laten dari faktor-faktor tersebut dapat berubah menjadi sikap sensitif. Beberapa analisis sosial berasumsi bahwa potensi konflik menjadi bersifat laten karena sistem pendidikan yang tidak mampu menyentuh aspek-aspek psikologis dalam konseling dan manajemen mental individu dalam berinteraksi dengan komunitas serta lingkungan sosialnya. Penelitian ini dikategorikan sebagai penelitian literature dan lapangan. mendeskripsikan atau memaparkan prasangka sosial dan stereotip etnik keagamaaan yang kita lihat di Indonesia serta berdasarkan pada hasil-hasil penelitian jurnal/buku-buku yang menjelaskan tentang stereotip etnik agama. Tulisan ini akan memaparkan bagaimana mengelola prasangka sosial dan stereotip etnik keagamaan melalui psychological dan global education dalam konteks pluralisme agama dan budaya.

Kata Kunci: Prasangka Sosial, Stereotip, Psychological, dan Global Education
\end{abstract}

\begin{abstract}
The series of conflicts that we see happening in Indonesia is inseparable from ethnic religion and culture, although there are factors such as structural inequality and system injustice. This factual reality might bring potential conflict, meaning that the latent danger of these factors can turn into a sensitive attitude. Some social analyzes assume that the potential for conflict becomes latent because the education system is unable to touch the psychological aspects of individual counseling and mental management in interacting with the community and its social environment. This study was categorized as literature research and field. describing or describing the social prejudices and ethnic stereotypes of religion that we see in Indonesia and based on the results of research journals/books that explain the stereotypes of ethnic religion. This paper will explain how to manage social prejudice and religious ethnic stereotypes through psychological and global education in the context of religious and cultural pluralism.
\end{abstract}

Keywords: Social Prejudice, Stereotypes, psychological, and Global Education. 


\section{Fitrah \\ $\triangle$ Jurnal Kajian Ilmu-ilmu Keislaman \\ Vol. 6 No. 1 June 2020}

\section{INTRODUCTION}

In recent years ethnic and religious variables have created such great confusion among social observers. Most of them are hoping that liberal modernization can blur ethnic differences, but not as expected. Other variables in the form of education and global communication will make society heterogeneous, but it doesn't turn out to be true. Starting with the phenomenon that occurred in the Indonesian capital of Jakarta in 2016, the Jakarta governor's election political contestation was completed which was won by Anies Rasyid Baswedan and Sandiaga Salahuddin Uno defeated incumbent Basuki Tjahja Purnama and Djarot Syamsudin. We can see together whether print, electronic, social and online media increasingly show social classes, one of the phenomena is the alleged blasphemy case of incumbent governor Basuki Tjahja Purnama (ahok) who was eventually sentenced to 2 years in prison. Thousands of masses, both from the pro-ahok and the counter-Ahok factions, carried out social upheaval, namely, prejudice against ethnicity and religion, and made silly movements that did not actualize the values of diversity and diversity of the Unitary State of the Republic of Indonesia.

The idea that ethnic, religious, and group equality can reduce conflicts is only intellectual fantasy. But in reality, this is not the case, cultural crises and conflicts caused by harmonious cultural interactions, or the phenomenon of coercion between cultures that has threatened the ideal goals of culture, namely harmony and peace. Forecast or more precisely the thesis put forward by Samuel $P$ Huntington about the occurrence of a clash of civilizations (class of civilization) which is loaded with ethnic and religious dimensions, despite receiving sharp criticism from various circles the discourse has become a matter of warm discussion in almost all circles until now. Especially when it turns out that in various regions ongoing riots are inter-ethnic violence. In his further description, Huntington added an interesting note that during the Cold War alone there were 32 massive-scale ethnic conflicts and 57 ethnopolitical conflicts. (Hallahmi \& Argyle, 1997, p. 155)

The reality is that there are many conflicts between ethnic, ethnic, religious, and cultural groups that at least justify the theoretical assumptions which state that cultural and religious pluralism is one of the potential horizontal conflicts. The fact also shows that the potential for religious and cultural pluralism against horizontal conflicts is indeed very high. Besides, dissatisfaction or injustice in the 
social, political, economic, and legal fields can be a contributor to conflict. While human nature was created by God on earth as a caliph, that is, given the task to build and develop it, therefore all his actions must be accountable to God.

\section{RESEARCH METHOD}

This study uses a qualitative method. This type of research is a literature study. In this paper, the author would like to invite all readers to find solutions to problems by using a multicultural theory analysis knife. How do we manage social prejudice and stereotypes of religious ethics through psychology and global education in the context of religious and cultural pluralism? Literature research is a study and systematically analyzed from books, journals, universities, and other sources relating to the material discussed in this study.

\section{RESULT AND DISCUSSION}

\section{Social Prejudice and Ethnic Stereotypes in Multicultural Interaction}

Understanding multicultural culture and the potential for conflict that arises is not something easy. One important variable that needs to be explored further is psychological aspects or typologies of psychosocial personality that shape cognition, attitudes, and social or group behavior and its relation to multicultural interactions. Studies of social psychology in the context of interfaith and cultural counseling can make a major contribution in explaining the phenomenon of emerging social conflicts and models of counseling therapy such as what can be done to reduce conflict latency. Some aspects that will be examined here are social prejudice and ethnic stereotyping.

1. Social Prejudice

Conventionally, in the dictionary, we can find the meaning of prejudice that is commonly defined as an assessment or opinion formed without first checking (judgment or opinion is formed beforehand or without due examination ", Chambers English Dictionary, 1998). This definition makes many social counseling psychologists find their inaccuracies define that ethnic prejudice is an antipathy based on false or inflexible generalizations. Prejudice can be directed towards a group as a whole or to someone because he is a member of the group. (Brown, 1995, p. 9)

From some of the explanations and changes in definition regarding prejudice, according to Augustinos and Reynolds (2001), the things underlying 


\section{Fitrah \\ $\triangle$ Jurnal Kajian Ilmu-ilmu Keislaman \\ Vol. 6 No. 1 June 2020}

prejudice can be concluded as an attempt or desire to demean other individuals or groups. (Putra, 2017, p. 7) This will be a problem because it will be very vulnerable to cause conflict and hatred between groups and individuals as group representatives. Prejudice comes from the socio-psychological drive, cognitive processes, and the influence of socio-cultural conditions on individuals and groups. This social prejudice also goes hand in hand with stereotypes. This term refers to a particular description or response regarding the personal traits and characteristics of people from other groups who are negative

It can be concluded that true prejudice is a phenomenon that is present in inter-group relations, not between individuals. Individuals who are targeted by prejudice are individuals who are part of the group, not because of the characteristics of the individual itself. Individuals are simplified into a unity of the same characteristics as the group, for example, phenomena that occur when they hate each other between ethnic groups or religions. The group that hates Ahok and Ahok's defenders. Besides that prejudice is a phenomenon that does not arise from anything, but departs from the process. This process occurs in groups, the first process that forms prejudice, for example, hatred of certain groups.

\section{Stereotype}

The stereotype is a perception that most members of a category have some of the same attributes. Stereotypes can originate from cultures in which people are socialized, from real cultural and socio-economic differences between groups, in The Blackwell Encyclopedia of social psychology defined as beliefs - beliefs about a person's characteristics (characteristics, personalities, personal values) that are accepted as a truth of social groups. For example, the Betawi people are very lazy, the Chinese are stingy. Ethnic stereotypes themselves are beliefs attached to other ethnic communities that are considered as hereditary truth and are always present within the community. (Brown, 1995, p. 127) For example, many people assume that Madurese have a hard and rude temperament in interacting socially with others, tend not to care about other people, and so on.

The author has explained what the prejudices and stereotypes are together, which refers to a particular picture or response regarding the personal characteristics and character of other negative people. Prejudice arises based on a previously existing belief, this belief is a picture of a group of people or individuals attributed to certain labels, this condition is called a stereotype. 
Research published by the American Psychological Association explains that in this modern global world there is still a bias of perception in white people in verbal behavior towards negroes. White people turned out to be more welcoming and friendly to their circles. (Dovidio et al., 2002, pp. 62-68) This means that in Indonesia also experiences conditions like this, Papuans have bad perceptions of white people, for example, Papuan children who have an education in Jogjakarta get the prejudice that they are rude, do not have ethics so white people do not want to get along with them. It is this condition that we can help through interfaith and cultural counseling.

Research on ethnic/cultural stereotypes carried out by a team from the University of British Columbia obtained important findings of the thin distance between the personal level and the cultural level. According to the research team, so far stereotypes have only been limited to personal-individual beliefs about a particular group. But stereotypes are also seen at the cultural level, which is a set of beliefs formed in certain communities as a result of the cultural process. (Schaller et al., 2002, p. 82)

So it is not surprising that stereotypes at this cultural level can trigger the formation of apologetic cognitions and social attitudes and truth claims. For example, the assumptions inherent in most Muslims will be very different from the views of Catholic-Christians about the Abbasid leadership in Spain. Muslims will claim that the presence of Islam in Spain is a blessing for Europe because the brilliant civilization of medieval Spain helped usher in the Renaissance. However, for Christian-Catholics the Islamic authority over Spain and many other occupied territories increasingly prove that Islam was spread through swords and war. (Kuntowijoyo, 2001, p. 38)

In everyday life, the embryo of apologetics and truth claims has unwittingly become an inseparable part of the Indonesian people. Often we comment at will on the existence of other religions and people. Or for example, there are many Muslims who think that the main enemy of Muslims is Christianity along with the birth of a radical movement. In the end, the mindset that settles in our mind consciousness forms a pattern of "us vs. them" social relations, a pattern that regards religious or other ethnic communities as common enemies that must be hated, disparaged, belittled, and even fought. Ironically, the paradigms of thinking, attitude patterns, and forms of action that are inherent in our personality have been transmitted genealogically to generations born later, 


\section{Fitrah \\ $\triangle$ Jurnal Kajian Ilmu-ilmu Keislaman \\ Vol. 6 No. 1 June 2020}

so we need as counselors to make preventive/anticipatory and curative efforts to avoid a negative prejudice.

\section{Multicultural Theory}

Pedersen (1999) proposes multiculturalism as the fourth power in the history of psychology, following humanism, behaviorism, and psychodynamics (Narvaez \& Hill, in press). At least, there are three large groups of multicultural studies in social psychology, namely multicultural as (a) social identity (b) social experience/interaction (c) state ideology and policy. As an ideology, multiculturalism is not automatically a practical policy, but there is a close relationship between the two. (Putra, 2017, pp. 129-134)

1. Multicultural Identity and Personality

The study of mixing two cultures, also called bicultural, is a study of individuals who have different cultural parents' backgrounds. In the beginning, psychology focused more on negative consequences, such as the confusion of identity, the pressure of two cultures, and conflicts within oneself that have identities of more than one culture. In its development, counseling psychology began to explore and find the positive impact of individuals who have a bicultural or multicultural identity. (Kim et al., 2006, p. 197)

Studies show that interactions between different cultures play a role in helping open mind-sets. This is inseparable from the demands of individuals to adjust and study continuously the two cultures they have in their basic social community (family). It should be noted that biculturalism is different and not the same as multiculturalism because multiculturalism can mean more than two cultures.

At the individual level, multicultural acts as a social identity, namely individual identity that is closely related to social interaction and personality (trait), not personal identity. The theory of social identity was conceived by social psychologist Henry Tajfel, who departed from the previous formulation of social categorization. In this view, every individual has a social categorization from birth to during his life development, such as gender as one of the basic social categories. (Putra, 2017, pp. 129-130) Individuals can choose the most beneficial, pleasing, and proud social identity, as a fan of the Ahok club related to the common vision and mission where he feels comfortable, possessed, and accepted. 
However, some basic social identities are difficult to avoid such as ethnicity, nation, and state. It is in this context that individuals with multicultural backgrounds have the opportunity to experience identity conflicts, including anxiety, self-concept, and self-esteem. This is because, in daily life, there are many negative stereotypes and prejudices between groups/community categorization. As global interaction develops prejudice against Muslims, Jews, and Africans. As in Indonesia, some ethnicities get less positive stereotypes, such as those with hard-tempered stereotypes, namely Batak, Bugis, Madura, or ethnic with stingy stereotypes such as Padang and Tiong Hoa as well as Javanese with slow stereotypes.

Although the community has its way of expressing it, as in-jokes and does not seem to matter much, the stereotype is conscious or cannot affect one's selfesteem and self-concept. For those who have a multicultural identity, there is a possibility that they will have an ethnic group which, according to their evaluation, has a few negative stereotypes in the community.

A person who has a multicultural personality is a person who tends to be able to be positive (confident) towards his group and accept outside groups. Thus multicultural identity is not always accompanied by multicultural personality, if the multicultural identity refers more to the inherent (internalbiological) aspect, then personality is the result of self-development. As in understanding personality, the patterns and characters that tend to be consistent and consistent with individuals.

Personality is a pattern of relatively permanent traits, dispositions, or characteristics that give some measure of consistency to a person's behavior. The point is that personality is a pattern that has relative characteristics, character, or permanent characteristics that provide an assessment of the consistency of a person's behavior. (Feist \& Feist, 2002, p. 4)

A person with a multicultural personality has high cultural sensitivity, is able to appreciate different cultures, tolerant, universally oriented, and cognitive flexibility. What defines the multicultural personality are factors such as the high development of racial and ethnic identity, tolerance, and appreciation of people for different religions and cultures, spiritual essence and a sense of community with others, self-reflection with flexible thinking in social interactions, initiatives in establishing contact with individuals who have diverse cultures, and activism is demonstrated by the willingness to fight social injustice in its various forms. 


\section{Fitrah \\ $\triangle$ Jurnal Kajian Ilmu-ilmu Keislaman \\ Vol. 6 No. 1 June 2020}

(Ponterotto et al., 2008, p. 74) Studies show that multicultural personality can significantly predict psychological strength, psychosocial interpersonal, and selfesteem.

2. Multicultural Experience

Multicultural stimuli or environments provide opportunities for multicultural personality development, related to creativity, which means there is something new, in a multicultural environment, individuals experience foreign things that require adaptation, tolerance, sensitivity, and also cognitive flexibility to survive. This intercultural contact predicts a decrease in racial prejudice while walking equally. Contacts that carry knowledge and friendship are likely to lead to healthier beliefs about minority groups, and thus contribute to prejudice unemployment. Contact itself often provides opportunities for tolerance between groups. (Wong \& Green, 2009, p. 228)

Indonesia as an archipelago that has diverse ethnicities and religions is a multicultural stimulus that can foster multicultural personalities and reduce racial prejudice. The condition is that contact is not merely cognitive knowledge about ethnicity/culture and religion. Contact can encourage the development of one's survival in other cultures, so that tolerance grows, cultural sensitivity to cognitive flexibility. To support the creation of equal and active inter-cultural interactions, the public needs more systematic and structural tools at the state institutional level.

3. Multicultural Ideology and Policy

Multicultural discussion in this section is no longer at the individual level and social interaction in society, but the level of ideology. Normatively, multiculturalism refers to an ideology about the positive value of attachment between various cultures, the equality of cultural groups, and requires the State to support diversity in various ways. The implementation, multicultural formulation can practically become a formal policy, this approach is to form and increase social cohesiveness by encouraging people to know each other and respect differences, not to equalize or unite in one culture or creed.

The multicultural policy encourages group rights over individuals, while groups demand (need) treatment is not the same as other groups. The controversy of the meaning of multiculturalism also occurs in the discussion of this policy, the meaning of multiculturalism broadly, including gender orientation, people with disabilities, and so forth. (Banting \& Soroka, 2006, p. 133) 
Indonesia has lived with diversity, it's just that the spirit or ideological basis of multiculturalism is not reflected in reality or formed in practical regulations. However, the diversity of Indonesian society is a challenge in all circles and especially in multicultural studies, because even before the immigration flow there was cultural diversity that had interacted with each other.

\section{Global Counseling and Psychological Counseling Approaches}

The purpose of this counseling is to help individuals or counselees master a variety of important life skills through structured programs organized in groups. Along with the occurrence of prejudice or prejudice conflicts, especially in Indonesia, the writer here offers the concept of counseling services to the children of the nation who will continue the relay of the struggle of the Indonesian people, namely a preventive effort in this counseling method that raises four ideas that need to be provided in counseling services, namely:(Hadar, 2019)
a. Expansion of educational insight
b. Identity Reflection
c. Changes in lifestyle
d. Relationship between global and local.

In the medium term, students throughout the world through Counseling Guidance teachers must be introduced to the key problems of the modern world, namely war and peace, the meaning, and problems of the principles of nationalism are linked to questions about cultural uniqueness and intercultural relations, problems with the environment especially relating to changes in awareness and lifestyle, social inequality, and the dangers of misuse of technological efficacy.

The philosophical tools that need attention are as follows:(Hadar, 2019)

a. Ideal human image (menschenbild) is he who is autonomous and responsible for gaining recognition and being able to judge clearly and ethically, be empowered, and open to change and learn throughout life.

b. The principles of global education proposed are related, holistic, experienceoriented or historical thinking, action orientation, social harmony, as well as active and dynamic without violence.

c. There is an integration of various institutions and educational planning, place, and atmosphere of learning, time structure, and teaching methods. 


\section{Fitrah \\ $\triangle$ Jurnal Kajian Ilmu-ilmu Keislaman \\ Vol. 6 No. 1 June 2020}

d. The creation of basic human competencies that have a sensitivity of observation, empathy, change of perspective, responsibility, self-reflection, cooperation, ability to resolve conflicts, and think systematically.

The philosophical tools above lead to a paradigm of "one world for all". Social factors that uphold it are aware of global dependence, the need for the information society, recognition of the existence of sub-cultures, gender partnerships, future orientation, sustainable development, and just society. This is a qualification that should be fulfilled and accessed by students, especially those who are at an early level of tertiary education. The point is that global counseling will become a bridge between capitalistic-globality values towards the internalization of democratic values and essential human togetherness. His hope is for peace without oppression.

Also, philosophical tools need to be enriched with methodical tools such as the knowledge society method or according to Peter Drucker (Jalaluddin Rakhmat) called Universal Literacy. The methods above were developed to provide understanding to children so that they become positive participants in the international arena who understand well the meaning and actions of empathy, trust, cooperation, and understanding the quality of their lives from the start and understanding shared values as values universal (we are living together). (Rakhmat, 1998, p. 28)

The keywords are life skills, which are empathetic listening and understanding, conveying messages, expressing thoughts and feelings, conflict resolution, making plans and problem solving, making decisions, coping with various stressors, undergoing various life transitions and developments successfully, and adjusting yourself with life in high school and college. (Corey, 2005, pp. 336-340)

In this context all, at the school level the role and function of mentors and counselors should be expanded, not only in personal support or counselor aides with responsibilities that tend to be administrative, but prepared to become counselors and trainers with individual approaches in the field of group life skills. In the target groups, they serve, mentors and counselors also prepare indigenous trainers among students (peer counseling approach, so that the presence of well-educated school counselors can have a multiplier effect towards the formation of a more personal and healthy school community. , effective and prosperous, in this way we hope to make a real contribution in efforts to alleviate 
or at least reduce our society and the school community in particular from crisis to a new, better life.

\section{CONCLUSION}

Indonesia as a multicultural country still needs a lot of empirical studies, especially social psychology to play an active role in creating harmony and reducing prejudice in its interactions. In the context and perspective of this brief and seemingly insufficient idea, a study of relief efforts, namely counseling services, efforts to reduce the escalation of potential conflicts, and the management of psychosocial aspects of individuals and groups is only one of many other intervention models. This touch on counseling and social personality aspects is in line with the general counseling goal which views that the formation of personal character includes two dimensions, namely the intellectualistic and holistic dimensions. The first dimension aims to assist students or counselees to achieve intellectual development optimally through curricular academic activities. The second dimension aims to assist the counselee, namely students to achieve personal growth and development as a whole, covering the personal, social, and intellectual aspects. 


\section{Fitrah

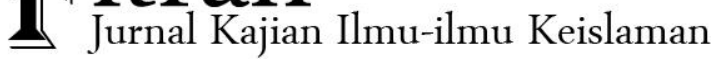 \\ Vol. 6 No. 1 June 2020}

\section{DAFTAR PUSTAKA}

Banting, K., \& Soroka. (2006). do Multiculturalism Policies Erorde the Welfare State: An Empirical Analysis. Oxford Univ Press.

Brown, R. (1995). Prejudice Its Social Psychology. Blackwell Publisher Inc.

Corey, G. (2005). Teori dan Praktek Konseling dan Psikoterapi Terj. Koeswara. Aditama.

Dovidio, J. F., Kawakami, K., \& Gaertner, S. L. (2002). Implicit and explicit prejudice and interracial interaction. Journal of Personality and Social Psychology, 82(1), 62-68. https://doi.org/10.1037/0022-3514.82.1.62

Feist, \& Feist. (2002). Theories of Personality. McGraw Hill.

Hadar, I. A. (2019). Pendidikan Global [Web Blog]. Kompas. http//www.kompas.com

Hallahmi, B. B., \& Argyle, M. (1997). The Psychology of Religious Behaviour, Belief, and Experience. Routledge.

Kim, U., Yang, K.-S., \& Hwang, K.-K. (2006). Indigenous and Cultural Psychology. Springer.

Kuntowijoyo. (2001). Muslim Tanpa Mesjid: Esai-esai Agama, Budaya, dan Politik Dalam Bingkai Strukturalisme Transendental. Mizan.

Ponterotto, Mendelowitz, \& Collaboleta. (2008). Promoting Multicultural Personality Development: A Strength-Based, Positive Psychology Worldview for School. Professional School Counseling.

Putra, I. E. (2017). Psikologi Prasangka. Ghalia Indonesia.

Rakhmat, J. (1998). Catatan Kang Jalal, Visi Media, Politik, dan Pendidikan. Rosda Karya.

Schaller, M., Conway III, L. G., \& Tanchuk, T. L. (2002). Selective pressures on the once and future contents of ethnic stereotypes: Effects of the communicability of traits. Journal of Personality and Social Psychology, 82(6), 861-877. https://doi.org/10.1037/0022-3514.82.6.861

Wong, \& Green. (2009). Tolerance and Contact Hypothesis: A Field Experiment. University Press. 